Session 2566

\title{
Achieving Those Difficult ABET Program Educational Outcomes Through a Capstone Design Course
}

\author{
Raymond M. Berg, Karim J. Nasr \\ Mechanical Engineering Department \\ Kettering University
}

\begin{abstract}
In July 2001, Kettering University implemented a reformed engineering curriculum and ABET Engineering Criteria 2000 assessment program. In accordance with EC 2000 Criterion 3, the Mechanical Engineering Department addressed the eleven ABET required program educational outcomes A-K, and also implemented eight additional M. E. program outcomes L-S based on professional societies input and departmental requirements. In preparing for this new curriculum and related assessment practices, the senior-level M. E. capstone design course "Plant and Facilities Design" was selected in October 2000 as a pilot course, for the development of the student capstone portfolio concept and the capstone outcomes assessment process.

In particular, the M. E. Department wished to determine best methods of demonstrating achievement of seven "difficult" or "non-traditional" program educational outcomes which have not classically been "taught" as part of the M. E. curriculum. These include: 1) an ability to function on multidisciplinary teams; 2) an understanding of professional and ethical responsibility; 3 ) the broad education necessary to understand the impact of engineering solutions in a global and societal context; 4) a recognition of the need for and an ability to engage in life-long learning; 5) a knowledge of contemporary issues; 6) an ability to manage engineering projects including the analysis of economic factors; and 7) an ability to understand the dynamics of people both in singular and group settings.
\end{abstract}

This paper presents the revisions made to the pilot capstone course, both to demonstrate preexisting student achievement of these seven outcomes, and to augment that achievement in the capstone course. This paper also presents the EC 2000 assessment strategies developed for the capstone course, and the results of course coordinator, peer and student assessments which demonstrate success in achieving these seven difficult outcomes.

Proceedings of the 2002 American Society for Engineering Education Annual Conference \& Exposition Copyright $\odot$ 2002, American Society for Engineering Education 


\section{Introduction}

Kettering University, like all accredited engineering schools, has adapted to ABET EC 2000. A formal curriculum reform process occurred over 1999-2001, and was implemented in July 2001 in accordance with EC 2000 criteria. Trial assessment practices began in Fall 2000, both for core courses and capstone design courses, and formal multi-tier, multi-method assessment review began in July 2001. The first EC 2000 accreditation visit is scheduled for Kettering University in Fall 2003.

The accreditation process of engineering programs has taken a new form, becoming an outcomebased process wherein individual courses and experiences must contribute to the big picture of engineering education. This process has caused the majority of engineering programs around the nation to reflect on their educational focus, examine teaching and learning styles, experiment with new and innovative approaches to assess students' learning, and above all put in place an improvement process ${ }^{[1]}$. In relation to ABET EC 2000's ${ }^{[2,3]}$ Criterion 3, Program Outcomes and Assessment, assessment and demonstration of outcomes achievement are not only a part of the improvement process, but also expected of any program desiring accreditation.

Without a doubt, a course housing the major design experience carries a greater responsibility in ensuring that students achieve specified program educational outcomes. According to EC 2000 ' $\mathrm{s}^{[3]}$ Criterion 4, Professional Component, "the curriculum must prepare students for engineering practice culminating in a major design experience based on the knowledge and skills acquired in earlier coursework, and incorporating engineering standards and realistic constraints that include most of the following considerations: economic, environmental, sustainability, manufacturability, ethical, health and safety, social, and political." The literature ${ }^{[4-8]}$ is filled with articles and papers on the "major design experience" course. Every program has one form or another of the so-called capstone design course. Some instructors focus on a step-by-step design process ${ }^{[4,6,9]}$, while others focus on incorporating industrial problems ${ }^{[10-13]}$ along with other considerations. Some instructors found that student understanding of concepts and their skills were enhanced by providing an active (cooperative) learning environment within the contexts of design, project management, communication, and ethics ${ }^{[14,15]}$. Recently, a number of capstone courses have been influenced by EC 2000 criteria, and instructors made a special effort in addressing such guidelines ${ }^{[16,17]}$. EC 2000 has a profound impact on the structure and content of the capstone course. Instructors, in addition to focusing on a design and an end product, must revisit how the course contributes to students' achievement of EC 2000 outcomes. Since a typical capstone course is taken by students near the end of their undergraduate studies, it builds on knowledge acquired from earlier coursework, and it makes use of technology to demonstrate achievement of soft and technical skills.

Kettering faculty considered this body of work in reviewing the course/thread/capstone sequence of study for an undergraduate mechanical engineer. Course-level correlation of student learning objectives to EC 2000 outcomes was performed for each course. It was generally found that most of the "traditional engineering" EC 2000 A-K outcomes, as well as the supplemental M. E.

Proceedings of the 2002 American Society for Engineering Education Annual Conference \& Exposition Copyright $\odot$ 2002, American Society for Engineering Education 
Department L-S outcomes, are amply assessed by the traditional mechanical engineering, crossengineering-discipline, science/mathematics and liberal sciences courses. In addition, the capstone design courses supplement this experience, particularly for the multi-disciplinary outcomes involving integrated design.

This paper describes the development of a capstone course-level assessment plan, presenting the performance criteria and metrics, grading and assessment methods, the continuous improvement process, and tracking and feedback from assessment cycles in 2000 and 2001. Two more assessment cycles will be completed prior to a Fall 2003 ABET accreditation visit.

For reference, the assessment survey in Appendix A of this paper summarizes the A-S outcomes currently employed by Kettering University's Mechanical Engineering Department.

\section{Identification and Basis for the Seven "Difficult" Outcomes}

After Kettering faculty had completed the initial cross-referencing of program educational outcomes versus the capstone student learning objectives, it was concluded that seven of the nineteen program educational outcomes needed stronger emphasis in the capstone course structure, content, learning methods and assessment practices. The general perception among faculty is that these seven outcomes are not formally "taught", nor presented or reviewed, as part of any mechanical engineering course structure or content. Why this is so may be explained on the basis of tradition, lack of time in the course schedule, instructor disinterest, lack of incentive or expertise, or disagreement as to whether they belong in M. E. courses or elsewhere in the general education component of the curriculum. The faculty did not attempt to resolve this fundamental issue, nor does this paper attempt to rationalize it. It was simply concluded that the senior-level M. E. capstone course process would be the vehicle to both demonstrate degree of outcomes achievement prior to coming to the course, and augment student achievement of the outcomes as much as possible within the course. Course content and structure revisions would be made to ensure achievement of these outcomes.

These seven outcomes are:

- $(\mathrm{ABET}) \mathrm{D}-\mathrm{An}$ Ability to Function on Multidisciplinary Teams

- (ABET) F - An Understanding of Professional and Ethical Responsibility

- $(\mathrm{ABET}) \mathrm{H}$ - The Broad Education Necessary to Understand the Impact of Engineering Solutions in a Global and Societal Context

- $(\mathrm{ABET}) \mathrm{I}-\mathrm{A}$ Recognition of the Need for and the Ability to Engage in Lifelong Learning

- (ABET) $\mathrm{J}-\mathrm{A}$ Knowledge of Contemporary Issues

- $(\mathrm{ME}) \mathrm{Q}$ - An Ability to Manage Engineering Projects, Including the Analysis of Economic Factors and Their Impact on the Design

- (ME) R - An Ability to Understand the Dynamics of People, Both in a Singular and Group Setting 


\section{Description of Capstone Design Course - MECH-520, Plant and Facilities Design}

To develop and demonstrate the process for the seven difficult outcomes and the related assessment practices, the existing M. E. capstone course MECH-520, entitled "Plant and Facilities Design", was selected for a pilot program in the Summer 2000 term. The course content and structure were reviewed and modified to address the seven outcomes, a student portfolio process was implemented, and two methods of outcomes assessment were developed. These assessments would include: 1) a review of the student portfolios against the ABET/ME outcomes by the course coordinator, the M. E. Department Assessment Team, and an independent review panel including members of an industrial advisory board and other universities, and 2) ABET outcomes surveys completed by students at the end of the course.

The course is structured on an 11-week term, offered twice per year. Typical enrollments are 2535 senior-level students per term. The enrollment is primarily mechanical engineers electing a cognate discipline of study, for whom this course is required. The course is also available as an elective for ME's, EE's and certain other students who can demonstrate knowledge of prerequisites. Cross-departmental student teams are welcomed.

The objective of the course is to provide an overall experience in the engineering and design of buildings and facilities. Students work in design teams to complete the design of a building and its infrastructure for a given residential, commercial or industrial purpose. The course covers site evaluations, structural, mechanical, electrical, instrumentation and controls, and auxiliary systems required for such buildings. Applicable codes, standards and governing laws are introduced as appropriate. Design layouts, simulations and project cost estimating are completed through appropriate software. Interaction with end users, oversight agencies and other third parties are introduced to simulate actual workplace situations.

The class divides itself at the first meeting into design teams of approximately 6-9 students. Students are assigned an actual university need, starting from a "green field" site condition. Student teams must assess, quantify and prioritize user needs through a formal data gathering and interview process. User needs are converted into a plant layout in 2-D and 3-D, after consideration and evaluation of design alternatives. Existing site conditions and restrictions are evaluated. A complete, iterative design process then ensues, covering foundation, structural frame, exterior and interior envelopes, mechanical equipment, electrical equipment, and auxiliaries, resulting in a completed conceptual design ready for detailed construction drawings. Code compliance is heavily emphasized. Interim design submittals are required throughout the course, with a final engineering/design report and oral presentation at the end of the course.

Typical design projects focus on the Kettering University campus. Recent projects have included:

- A University Transportation Research Center

- A Fraternity/Sorority House and University Guest Suites

- A Concert Hall and University Advancement Offices

Proceedings of the 2002 American Society for Engineering Education Annual Conference \& Exposition Copyright $\odot$ 2002, American Society for Engineering Education 
- A University Bookstore and Coffee Shop

- A University Research/Business Incubator Building

\section{Capstone Design Student Learning Objectives}

We began this process in 1999 by first redefining the student learning objectives for MECH-520, Plant and Facilities Design, in accordance with EC 2000 criteria:

Objective 1: To obtain a fundamental understanding of the integrated design issues in building and facilities design, and the appropriate problem solving methodologies for each of the disciplines involved, and to apply current numerical and data analysis techniques to each step of the problem.

Objective 2: To formulate the design problem, to synthesize the design process, to establish a systematic approach to resolving multi-disciplinary design issues, and to work collaboratively as a team in a multi-disciplinary environment.

Objective 3: To apply fundamental engineering practices and design knowledge gained in earlier courses into an integrated, real-world application, typical of what may be encountered in the industrial or commercial workplace. To develop the design while preparing an overall project cost estimate, and learning to consider economic constraints in material selections.

Objective 4: To develop an appreciation of the real-world issues which govern and often place restrictions on the practice of engineering and design, to become familiar with regulatory bodies, and to understand the need and importance of continuous improvement in safety within engineering.

Objective 5: To develop an understanding of optimizing designs through iterative processes, and the importance of continuous quality improvements over the product design cycle.

Objective 6: To develop an awareness of ethics in the design process, and an understanding and appreciation of the needs of disabled persons in our society. To consider society as a whole in the design of buildings and facilities.

Objective 7: To develop the ability to interact with managers and authority entities, to learn how to consider, evaluate and process direction received from others, and then how to turn around and provide such direction to others.

We then linked these seven student learning objectives to the nineteen ABET/ME outcomes. Table 1 exhibits how the learning objectives of this capstone course map to ABET's educational 
outcomes (A-K) and the additional program-specific educational outcomes (L-S). The marked boxes indicate a "high" or "very high" correlation between the student learning objective and the ABET/ME outcome. Refer to Appendix A for a text description of the A-S outcomes.

Table 1. Correspondence between the capstone student learning objectives and ABET/ME program educational outcomes $(\mathrm{A}-\mathrm{S})$.

\begin{tabular}{|c|c|c|c|c|c|c|c|c|c|c|c|c|c|c|c|c|c|c|c|c|}
\hline \multirow{9}{*}{ 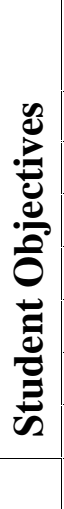 } & \multicolumn{20}{|c|}{$\begin{array}{l}\text { Program Outcomes: ABET's EC } 2000 \text { Outcomes (A - K) and } \\
\text { Additional M. E. Dept. Outcomes (L-S) }\end{array}$} \\
\hline & & $\mathbf{A}$ & B & $\mathbf{C}$ & D & $\mathbf{E}$ & $\mathbf{F}$ & $\mathbf{G}$ & $\mathbf{H}$ & I & $\mathbf{J}$ & $\mathbf{K}$ & $\mathbf{L}$ & $\mathbf{M}$ & $\mathbf{N}$ & $\mathbf{O}$ & $\mathbf{P}$ & $\mathbf{Q}$ & $\mathbf{R}$ & $\mathbf{S}$ \\
\hline & 1 & $\mathrm{X}$ & & $\mathrm{X}$ & & $\mathrm{X}$ & & & & & X & X & $\mathrm{X}$ & $\mathrm{X}$ & & X & & & & $X$ \\
\hline & 2 & X & & $\mathrm{X}$ & $\mathrm{X}$ & $\mathrm{X}$ & $X$ & $\mathrm{X}$ & $\mathrm{X}$ & & $\mathrm{X}$ & X & $\mathrm{X}$ & $\mathrm{X}$ & & X & & $\mathrm{X}$ & $\mathrm{x}$ & $X$ \\
\hline & 3 & $\mathrm{X}$ & & $\mathrm{X}$ & $\mathrm{X}$ & $\mathrm{X}$ & & $\mathrm{X}$ & $\mathrm{X}$ & & $\mathrm{X}$ & $\mathrm{X}$ & $\mathrm{X}$ & $\mathrm{X}$ & & & & $\mathrm{X}$ & & $\mathrm{X}$ \\
\hline & 4 & & & $\mathrm{X}$ & $\mathrm{X}$ & $\mathrm{X}$ & $\mathrm{X}$ & $\mathrm{X}$ & $\mathrm{X}$ & $\mathrm{X}$ & $\mathrm{X}$ & $\mathrm{X}$ & & $\mathrm{X}$ & & & & $\mathrm{X}$ & & $\mathrm{X}$ \\
\hline & 5 & $\mathrm{x}$ & & $\mathrm{X}$ & $\mathrm{X}$ & $\mathrm{X}$ & & & $\mathrm{X}$ & & $\mathrm{X}$ & $\mathrm{X}$ & $\mathrm{X}$ & $\mathrm{X}$ & & & & $\mathrm{X}$ & & $\mathrm{X}$ \\
\hline & 6 & & & & & & $X$ & & X & & $\mathrm{X}$ & & & & & & & & & \\
\hline & 7 & & & & $\mathrm{X}$ & & & $\mathrm{X}$ & & & X & & & & & & & $X$ & X & \\
\hline
\end{tabular}

Outcomes B and N (design/conduct of experiments, automatic data acquisition, data reduction, and analysis/interpretation of data) do not score high in this course, because no experiments are actually conducted in this course, although students make extensive use of field data collected by others. These outcomes are heavily addressed by another required M. E. laboratory course, usually taken concurrently by senior students. Outcome P (knowledge of chemistry and calculusbased physics) is also demonstrated in other courses.

Outcome I (engage in life-long learning) became a major focus of redesign in this capstone class. Outcomes D (function on multi-disciplinary teams), F (professional and ethical responsibility), H (broad education - impact global and societal context), J (knowledge of contemporary issues), $\mathrm{Q}$ (management of engineering projects with economic constraints), and R (dynamics of people in singular and group settings) were also recognized as important elements requiring strengthening of the prior course syllabus, content and methods of teaching.

\section{Rebuild of the Course Syllabus, Content and Teaching Methods}

Beginning in 1999, and continuing through 2001, several specific changes were implemented to address these seven difficult outcomes. The basic challenge was inserting these changes into an already-packed syllabus and still expecting students to successfully achieve the student learning objectives (i.e., putting twenty pounds of content in a ten pound sack). This required several iterations to get the right mix.

For each of the difficult outcomes, the following changes and additions were made to the course:

Proceedings of the 2002 American Society for Engineering Education Annual Conference \& Exposition Copyright (C) 2002, American Society for Engineering Education 


\section{ABET EC 2000 Outcomes}

D - An ability to function on multidisciplinary teams

1. Student teams are self-appointed in the first hour of class. Students must decide on team partnering fairly quickly. Generally, they know each other well, and this goes relatively smoothly.

2. Team members set up web pages or other forms of common electronic communication among themselves and the instructor.

3. Student teams police themselves and can throw a non-performing member off the team.

4. Teams must report work delegation assignments to instructor, and demonstrate crossdisciplinary sharing. The course has been redesigned to include aspects of structural, mechanical, electrical, HVAC and lighting, many elements of which are crossiterative, and require team members to continuously feed updated information back and forth.

5. Student team members complete detailed self-assessment and other team member assessments of performance and contribution at course end.

$\mathrm{F}$ - An understanding of professional and ethical responsibility

1. Projects must demonstrate conformance to the Americans with Disabilities Act. Students must sit in and utilize wheelchairs on a hilly campus, for better understanding of disability issues. Students review their design with a disabled representative of a local advocacy agency (the students' awareness of disability issues is greatly increased at this session).

2. Students watch the PBS NOVA series video "Super Bridge"[18], which covers the construction of the Clark Bridge over the Mississippi River, In particular, the video demonstrates the ethical dilemma and contractor deliberations of expensive structural rework done during construction. Students are required to analyze and determine if they agree with the resolutions reached in the video, and what alternatives there may have been.

3. Two case studies (required reading/analysis/discussion) involving design and ethics responsibility: Henry Petroski's analysis in American Scientist ${ }^{[19]}$, "Vanities of the Bonfire", on the collapse of the Texas A\&M University Bonfire, and the design of a new local high school which discriminated against disabled persons while still meeting all requirements of building codes.

$\mathrm{H}$ - The broad education necessary to understand the impact of engineering solutions in a global and societal context

1. A workshop is held with representatives of the Kettering University architect-engineer, who reviews ongoing university building projects and the issues involved with agencies such as the local zoning board, the central community redevelopment agency, the state Department of Natural Resources (the campus is located on a major river), and national energy efficiency requirements. Student projects are reviewed versus these inputs.

Proceedings of the 2002 American Society for Engineering Education Annual Conference \& Exposition Copyright $\odot$ 2002, American Society for Engineering Education 
2. Student teams are required to contact a variety of persons and organizations for global project input, including the university President, the local zoning office, the ultimate users of the facility including members of the immediate business community and the general public, and professional or commercial entities with structures similar to the team's. Internet communication with suppliers and other parties is required.

I - A recognition of the need for and the ability to engage in life-long learning

1. Student teams interact weekly with the university's Facilities Department, who volunteer extensive time to the teams. However, these persons are often likely to point students to current trade publications, code books and other materials in their office that they receive continuously as part of their occupation, rather than answer student questions directly, which impresses on students how much one needs to keep up in a given field.

2. The architect-engineer workshop referenced in Item $\mathrm{H}$ above also covers the continuous training and refresher requirements for professional engineers in the building and architect businesses.

3. Through the students' extensive Internet searching and communication with suppliers of products, the concept of using the Internet as an efficient and expedient tool for continuous learning and updating of knowledge is reinforced.

$\mathrm{J}$ - A knowledge of contemporary issues

1. Kettering University recently received a donation of several parcels of land with environmental issues. Students are familiarized with the issues involved in site remediation and the negotiations ongoing with the donator, a major industrial corporation, particularly as to where their building may sit on this land.

2. Sick building syndrome, ADA and equal access requirements, and low emissions equipment requirements have been added to the class.

3. After September 11, 2001, a segment has been added utilizing Christopher M. Foley's article "Why They Fell" in ASEE Prism ${ }^{[20]}$, examining to what extent building engineers can and should consider catastrophic events such as the attacks on the World Trade Center in the design of the building structure.

\section{E. Department Outcomes}

Q - An ability to manage engineering projects including the analysis of economic factors

1. Student teams are required to design their structure to a fixed cost target comparable to current commercial building costs, using actual building direct cost data and overhead/profit factors for the Flint, Michigan area. Software and commercial cost estimating routines have been purchased to assist with this.

2. The multi-disciplinary design is by nature iterative, so student teams must constantly balance such issues as structural dead/live loads, fire resistivity, building cost targets and aesthetics of the design, all while meeting the users' defined needs.

3. The teams are continually being critiqued on their designs and cost by various university officials, including the course instructor.

Proceedings of the 2002 American Society for Engineering Education Annual Conference \& Exposition Copyright $\odot$ 2002, American Society for Engineering Education 
$\mathrm{R}$ - An ability to understand the dynamics of people both in singular and group settings

1. Student teams are required to interview the university President, various vice-presidents, and persons outside the university structure, for input to the project. For many students, this represents their first one-on-one conversation with the university President and other officials. They must learn to both focus their questioning due to the very busy schedules of these people, and to accept their input as not personal but professional critique. These same university officials may attend their final oral presentation, and students must be able to think quickly and clearly regarding their questions.

2. The students must often reconcile conflicting direction given by the university President and one of his subordinates on a building use or function. This engenders great consternation and discussion among team members, who seek a Solomon-like resolution from the instructor, who doesn't provide it. Students must learn how to reconcile the often conflicting demands of various persons, and develop compromising and consensusbuilding skills within the group and with other university personnel.

3. The team interactions with university personnel and with each other are often monitored by the instructor, who e-mails observations with suggestions to the team about their personal and group interactions.

This process is continually refined each time the course is taught. The limiting factor now is simply the available weekly contact hours (four formal, approximately 1-2 informal) the instructor has with the student teams, plus some Internet contact with student design web pages. After the Fall 2001 offering of this class, the limit of available time to add additional case studies and examples has been reached, without dropping some element of the core course content.

\section{The EC 2000 Assessment Process Applied to the Restructured Capstone Course}

There are a number of references in the literature which focus on assessment methodologies, presenting techniques such as surveys, portfolios, entrance and exit interviews, teaching goals inventories (TGI's), and many others ${ }^{[21-25]}$. In developing this revised capstone course, the student learning objectives were formulated, tied into, and made consistent with the overall program educational outcomes, as discussed earlier in this paper.

To assess the effectiveness of the revised capstone course, particularly in regards to the student learning objectives and the seven difficult outcomes, two assessment methods were performed: 1) a capstone student portfolio review and 2) an end-of-course outcomes-based survey.

\section{The Initial Capstone Student Portfolio Review (“Cycle 0")}

A course coordinator review of student capstone portfolios versus the nineteen outcomes and the student learning objectives was completed in October 2000, prior to the implementation of the revised M. E. Department curriculum under EC 2000. This initial assessment was referred to as "Cycle 0". The course coordinator identified target levels of student achievement on a 0-3 (lowvery high) scale, and evaluated actual achievement of student outcomes through portfolio content

\section{Proceedings of the 2002 American Society for Engineering Education Annual Conference \& Exposition} Copyright $\odot$ 2002, American Society for Engineering Education 
review. This effort was performed about $75 \%$ of the way through the "course overhaul" process described earlier in this paper.

The student portfolio contents included: the final report, eight interim design reports, eight interim grade sheets with instructor commentary, student team assessment reports, a CD of the final presentation materials, and a videotape of the final presentation. The coordinator documented the review with commentary on each finding. The review demonstrated generally good matching between coordinator expectations for the course structure and student demonstrated achievement. Based on the review, four improvements were identified for implementation in 2001-2002:

1. Addition of a hydraulic design tool for building water system design, and strengthening of course content in this topic.

2. Resident Kettering architect/engineer seminar on societal and ethical issues, addition of Petroski Bonfire analysis and NOVA bridge video.

3. Purchase and provision of building 3-D visualization software to facilitate design.

4. Addition of on-line Blackboard ${ }^{\mathrm{TM}}{ }^{[26]}$ outcomes-based course survey.

The results of this Cycle 0 assessment have been presented to departmental and university level assessment personnel for critique of both methods and findings. No additional changes to the methodology or course improvements have been identified based on this independent review.

\section{The Student End-of-Course Outcomes-Based Survey ("Cycle 1")}

Items 1, 2 and 4 above were implemented. Item 3 has gradually resolved itself due to CAE curriculum improvements implemented over the last 2-3 years at Kettering. The portfolio assessment also led to slight adjustments in some of the course coordinator's targets for the ABET/ME outcomes over what had been initially defined in 1999. This paved the way for an outcomes-based course survey. An end-of-course Blackboard ${ }^{\mathrm{TM}}$ on-line survey was completed by MECH-520 Plant and Facilities Design students in December 2001, for the purpose of assessing the students' perspective on the contribution of this course in achieving the nineteen program educational outcomes. Appendix A features the skeleton of this survey, listing the nineteen program educational outcomes and a scoring system. Students were asked to select the score closest to their perception of the course demonstration of the outcomes. Data was compiled in the Blackboard ${ }^{\mathrm{TM}}$ system, and the results are presented in terms of rating levels in Figure 1. Also plotted on the same figure is the course coordinator's target expectation of the level of achievement for these outcomes.

The results of this assessment survey are very encouraging and supportive of a successful correspondence of this capstone building design course to EC 2000 outcomes. The survey results show very good correlation between course coordinator target objectives and student perception of their achievement of those outcomes. 


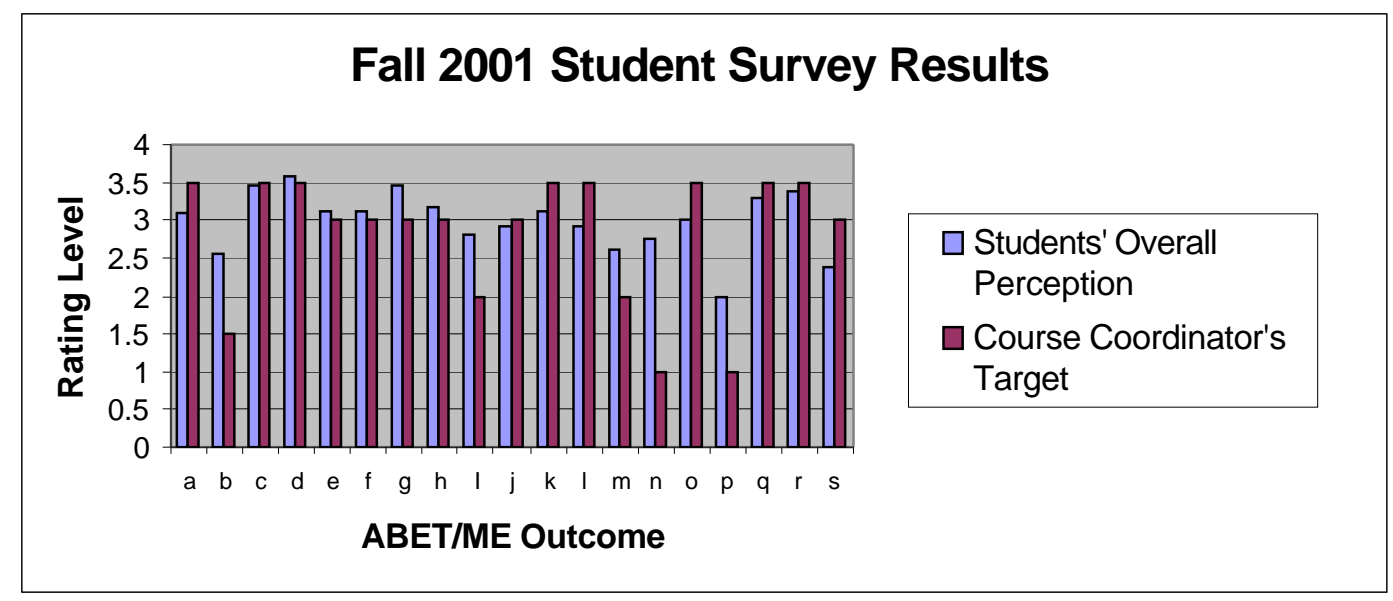

Figure 1. Comparison of students' perception of outcomes achievement versus the course coordinator's target achievement level.

In particular, the following results are noted for the seven difficult outcomes as shown in Table 2:

Table 2. Tabulated comparison between coordinator's target and students' perception

\begin{tabular}{|l|l|l|}
\hline Outcome & Coordinator Target & Students Perception \\
\hline D - Multidisciplinary Teams & 3.5 & 3.57 \\
\hline F - Prof./Ethical Responsibility & 3.0 & 3.12 \\
\hline H - Global/Societal Impact & 3.0 & 3.19 \\
\hline I - Life-Long Learning & 2.0 & 2.82 \\
\hline J - Contemporary Issues & 3.0 & 2.93 \\
\hline Q - Proj. Management/Costs & 3.5 & 3.29 \\
\hline R - Dynamics of People & 3.5 & 3.39 \\
\hline
\end{tabular}

These results are very encouraging, indicating success at adapting to the seven difficult outcomes in the restructured capstone course. We are particularly pleased by the excellent score in Outcome I, Life-Long Learning, as we viewed this initially as one of the most difficult to achieve.

This initial work is being supplemented by the following, to define any further improvements to this particular capstone design course relative to the ABET/ME outcomes, and to assist with the capstone design courses in general, as well as prepare for the Fall 2003 accreditation visit:

1. All capstone course students are completing a "whole-program" Blackboard" evaluate their entire undergraduate experience relative to the nineteen outcomes.

2. We will continue with student portfolio reviews and on-line course-specific student surveys twice per year, to validate information previously determined. Cycle 2 will occur in Winter Term 2002. An M. E. Department off-site assessment retreat in Winter 2002 will also allow

Proceedings of the 2002 American Society for Engineering Education Annual Conference \& Exposition Copyright ( 2002, American Society for Engineering Education 
full faculty review of the capstone assessment results to date. A complete Cycle 3 will be performed before the ABET accreditation visit in Fall 2003. The course coordinator will have at that time approximately 15 student portfolios and 3 sets of survey data for ABET review.

3. Independent review and assessment of student portfolios will be performed by an outside advisory board, consisting of M. E. Department faculty, members of Kettering's M. E. Industrial Advisory Board, and academic faculty from another engineering institution. This will occur in Spring 2002.

4. The results from these capstone surveys and portfolio reviews will be supplemented by Education Benchmark, Inc. surveys conducted of outgoing students and recent Kettering graduates, which also measure the total undergraduate experience much like the capstone courses do.

\section{Conclusion}

This paper demonstrates that ABET EC 2000 and department-specific program educational outcomes which are classically thought of as "non-traditional" for an undergraduate mechanical engineering program can be successfully achieved by conscious revisions to capstone design course content, structure and teaching methods. Multiple, independent assessment techniques bring validity to the success of the outcomes-based engineering program. The result is a greatly improved teaching and learning experience, facilitated by continuous improvement typical of the engineering profession to which our students will enter.

\section{Bibliography}

1. Patterson, G.K., "Preparing for the First ABET Accreditation Visit Under Criteria 2000", ASEE Proceedings, Charlotte, N.C. (1999).

2. Accreditation Board for Engineering and Technology (ABET), Engineering Criteria 2000, How do you measure success, ASEE Professional Books (1998).

3. http://www.abet.org/images/eac_criteria_b.pdf.

4. Todd, R. H., et al., "A Survey of Capstone Engineering Courses in North America", Journal of Engineering Education, Vol. 84, No. 2, 1995, pp. 165 - 174.

5. McEwen, E., "Integrated Capstone Design Experience", Journal of Professional Issues in Engineering Education and Practice, V. 120, No. 2, April 1994, pp. 212 - 220.

6. Thigpen, L., and Glakpe, E., "Capstone Design Experience in Mechanical Engineering at Howard University", $29^{\text {th }}$ Annual Frontiers in Education Conference, Nov 10 - 13 (1999), pp. 11b2-25 - 11b2-29.

7. Neumann, W., Woodfill, M., "A Comparison of Alternative Approaches to the Capstone Experience: Case Studies versus Collaborative Projects", $28^{\text {th }}$ Annual Frontiers Education Conference, Nov 1998, pp. 470 - 474.

8. Heitman, G., and Manseur, R., "Organization of a Capstone Design Course", $30^{\text {th }}$ Annual Frontiers in Education Conference, Oct $18-21$ (2000), pp. F1C-1 - F1C-5.

9. Mertz, R., “A Capstone Design Course”, IEEE Transactions on Education, Vol. 40, No. 1, Feb. 1997.

10. Paulik, M., and Krishnan, M., "Autonomous Ground Vehicle Competition-Driven Capstone Design Course", $29^{\text {th }}$ Annual Frontiers in Education Conference, Nov 10 - 13 (1999), pp. 12b4-7 - 12b4-12.

11. Todd, R., Sorensen, C., and Magleby, S., "Designing a Senior Capstone Course to Satisfy Industrial Customers", Journal of Engineering Education, V. 82, No. 2, April 1993, pp. 92 - 100.

\section{Proceedings of the 2002 American Society for Engineering Education Annual Conference \& Exposition} Copyright $\odot$ 2002, American Society for Engineering Education 
12. Deleveaux, V., and Ruud, C., "Designing and Teaching a Successful Industry Based Capstone Design Course", ASEE Annual Conference Proceedings, Jun 15-18, 1997.

13. Fillo, J., "Capstone Senior Design Course Through Industry Collaboration", ASME International Mechanical Engineering Congress and Exposition, Anaheim, Nov 15 -20, 1998.

14. Rover, D., "Perspectives on Learning in a Capstone Course", $30^{\text {th }}$ Annual Frontiers in Education Conference, Oct $18-21$ (2000), pp. F4C-14 - F4C-19.

15. Pimmel, R., "Cooperative Learning Instructional Activities in a Capstone Design Course", Journal of Engineering Education, Vol. 90, No. 3, 2001, pp. 413 - 421.

16. Ravikumar, P., "Assessing and Improving a Senior Design Project Course for Undergraduates in Mechanical Engineering Based on New ABET Guidelines", ASEE Annual Conference Proceedings, 2001.

17. Tooly, M., and Hall, K., "Using a Capstone Design Course to Facilitate ABET 2000 Program Outcomes", ASEE Annual Conference \& Exposition Proceedings, Jun 24-27, 2001, Albuquerque.

18. "Super Bridge", PBS NOVA Series, WGBH Educational Foundation, Neil Goodwin - Producer, Thomas Friedman and Neil Goodwin - Writers, 1997.

19. Petroski, Henry, "Vanities of the Bonfire", American Scientist, Volume 88, Pages 486 - 490, Nov.-Dec. 2000.

20. Foley, Christopher M., "Why They Fell", ASEE Prism, December 2001, pages 6-7.

21. Angelo, T., and Cross, P., "Classroom Assessment Techniques: A Handbook for College Teachers", JosseyBass Publishers, San Francisco (1993).

22. Nichols, J.,"A Practitioner's Handbook for Institutional Effectiveness and Student Outcomes Assessment Implementation", Agathon Press, New York (1995).

23. Race, P., and Brown, S., "The Lecturer's Toolkit: A Practical Guide to Teaching, Learning, and Assessment", Kogan Page, London (1998).

24. Pintar, A.J., Aller, B.M., Rogers, T.N, Sculz, K.H., and Shonnard, D.R., "Developing an Assessment Plan to Meet ABET EC2000", ASEE Proceedings, Charlotte, N.C. (1999).

25. Trevisan, M.S., Davis, D.C., Calkins, D.E., and Gentili, K.L., : "Designing Sound Scoring Criteria for Assessing Student Performance", Journal of Engineering Education, (1999).

26. Trademark of Blackboard, Inc., www.blackboard.com.

\section{RAYMOND M. BERG}

Mr. Berg is an associate professor of Mechanical Engineering at Kettering University (formerly GMI Engineering \& Management Institute). He teaches in heat transfer, fluid mechanics, and building and facilities design. He joined the university in 1994, after 25 years of industrial practice as a nuclear power engineer and co-owner of an architectengineering firm. He also coordinates several consulting and research projects for industrial clients at Kettering.

\section{KARIM J. NASR}

Dr. Nasr is an associate professor of Mechanical Engineering at Kettering University (formerly GMI Engineering \& Management Institute). He is a member of the ME Assessment Team and an EC2000 program evaluator. His current activities involve teaching thermodynamics, fluid mechanics, and heat transfer, developing new courses, and performing experimental and numerical investigations on fluid flow and thermal problems. 


\section{Appendix A: Outcomes-Based Student Assessment Survey}

Recognizing that each course has its own learning objectives and outcomes, please rate the contribution of THIS COURSE in meeting the M.E. program educational outcomes:

A. Ability to apply knowledge of mathematics, science and engineering.

B. Ability to design and conduct experiments, as well as to analyze and interpret data.

C. Ability to design a system, component, or process to meet desired needs.

D. Ability to function in multidisciplinary teams.

E. Ability to identify, formulate and solve engineering problems.

F. Understanding of professional and ethical responsibility.

G. Abilitv to communicate effectivelv.

$\mathrm{H}$. Broad education that is necessary for understanding the impact of engineering solutions in a global and societal environment.

I. Recognition of the need for engaging in life-long learning activities.

J. Knowledge of contemporary issues.

$\mathrm{K}$. Ability to use the techniques, skills and modern engineering tools necessary to perform effectively in an engineering setting.

L. Ability to work professionally in both thermal and mechanical systems areas including the design and realization of such systems.

M. Competence in the use of computational mathematics tools germane to the world of engineering.

N. Competence in experimental design, automatic data acquisition, data analysis, data reduction. and data presentation. both orallv and in the written form.

O. Competence in the use of computer graphics for design communication and visualization.

P. Knowledge of chemistry and calculus based physics

Q. Ability to manage engineering projects including the analysis of economic factors and their impact on the design.

R. Ability to understand the dynamics of people both in a singular and group setting.

$\begin{array}{lllll}\text { A } & \text { B } & \text { C } & \text { D } & \text { E } \\ \text { A } & \text { B } & \text { C } & \text { D } & \text { E } \\ \text { A } & \text { B } & \text { C } & \text { D } & \text { E } \\ \text { A } & \text { B } & \text { C } & \text { D } & \text { E } \\ \text { A } & \text { B } & \text { C } & \text { D } & \text { E } \\ \text { A } & \text { B } & \text { C } & \text { D } & \text { E } \\ \text { A } & \text { B } & \text { C } & \text { D } & \text { E } \\ \text { A } & \text { B } & \text { C } & \text { D } & \text { E }\end{array}$

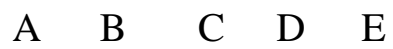

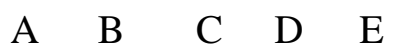

A $\quad$ B $\quad$ C $\quad$ D $\quad$ E

A $B \quad$ C $D$ E

A $\quad$ B $\quad$ C $\quad$ D $\quad$ E

A $\quad$ B $\quad$ C $\quad$ D $\quad$ E

A $\quad$ B $\quad$ C $\quad$ D $\quad$ E

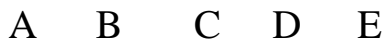

A $\quad$ B $\quad$ C $\quad$ D $\quad$ E

A $\quad$ B $\quad$ C $\quad$ D $\quad$ E

$\mathrm{A}=$ High Contribution, $\mathrm{B}=$ Above Average, $\mathrm{C}=$ Average, $\mathrm{D}=$ Below Average, and $\mathrm{E}=$ Not Applicable . 